Article

\title{
Competitive Capabilities for the Innovation and Performance of Spanish Construction Companies
}

\author{
José Giménez ${ }^{1}$, Antonia Madrid-Guijarro ${ }^{2, *(1)}$ and Antonio Duréndez ${ }^{2}$ (i) \\ 1 Facultad de Ciencias de la Empresa, Technical University of Cartagena (UPCT), Calle Real, 3, 30201 \\ Cartagena, Spain; josegimenezsa@gmail.com \\ 2 Department of Economics, Accounting and Finance, Faculty of Business Studies, \\ Technical University of Cartagena (UPCT), Calle Real, 3, 30201 Cartagena, Spain; antonio.durendez@upct.es \\ * Correspondence: antonia.madrid@upct.es
}

Received: 2 September 2019; Accepted: 29 September 2019; Published: 2 October 2019

check for updates

\begin{abstract}
This research analyses the influence of internal capabilities, identified as strategic by the literature, on the performance and innovation of Spanish construction companies during a recessionary period. Based on this, we studied whether innovative, marketing, financial, managerial, and human capabilities affect competitive success in terms of fostering innovation and the performance of firms. Empirical evidence is provided by performing survey research with a sample of 94 Spanish construction firms. The results show that firm innovation is fostered by innovative, financial, and human capabilities, and that performance is promoted by innovation, and financial and human capabilities. Human capabilities have the most important effect on both innovation and the performance of the company.
\end{abstract}

Keywords: innovation; performance; construction firms; human capability; financial capability; marketing capability; managerial capability; Partial Least Square; recessionary period

\section{Introduction}

The construction sector represents one of the most impactful economic activities in the world [1-3]. Construction is important for sustaining worldwide development [4,5], because the success of this industry leads to the promotion and maintenance of long-term economic growth and stability $[6,7]$. Thus, it provides a significant percentage of many countries' gross domestic product (GDP) [7].

In Spain, the importance of construction activities is also evident, because of their contribution to the Spanish growth domestic product (GDP), and by extension, because of their effect on other industries [8-11]. Therefore, this sector contributes to the productivity and long-term growth and competitiveness of the Spanish economy [10-13]. Furthermore, this sector has a huge capacity to generate both direct and indirect employment [8-10,12]. During the previous economic recession, the Spanish construction sector became the epicentre of the crisis, suffering a strong downturn [14]. Despite this critical situation, the influence of construction on the Spanish economy remained higher than in other European countries [11,15].

In a dynamic, increasingly competitive economy, identifying the factors that can affect business success can be useful in order to implement strategies aimed at improving firms' resources and capabilities, and boosting their innovative activity and performance [16]. As pointed out by Simion-Melinte and Istrate [15], and Álvarez et al. [10], the previous statement is especially important for the construction sector, because of its influence on other sectors. Previous empirical papers focus on the factors that foster business competitiveness and performance. Authors have dealt with innovation as a competitive factor [5,17]; opportunities that different phases of construction create for innovation [18]; the effect that relationships and partnerships among the partners of a project 
have on innovation $[19,20]$; the standardisation of innovation [17] and its effect on organisation and client satisfaction [21]; innovation and scale economies [8,22]; and the cost, speed of construction, and duration of projects [23]. Unfortunately, although innovation has been identified as a key factor in competitiveness, the construction industry is well-known for its low level of innovation both internationally and in the Spanish case [11,24].

We are responding to the research gap identified in previous literature by $\mathrm{Yu}$ and Yang [3], and Kabirifar and Mojtahedi [7], in relation to the need to identify those strategic factors that should guide managers toward a successful competitive orientation in a sector that is key for the economy. The purpose of this paper is to determine the factors that explain the state of business success in the Spanish construction sector by defining the relationship between the endowment of resources and the capabilities that companies deploy in order to compete and innovate. In this work, taking the validity of these antecedents as a reference, an explanatory model of competitiveness is proposed. This model analyses the influence of internal capabilities, identified as strategic by the literature, on the performance and innovation of Spanish construction companies. In this sense, we are studying whether innovative, marketing, financial, managerial, and human capabilities affect competitive success in terms of fostering innovation and performance. The research question we try to answer is as follows: what capabilities can Spanish construction companies develop to promote innovation and performance? Thus, we aim to identify the key internal factors that lead to the development of sustainable competitive advantages in the Spanish construction sector. An empirical study has been carried out on a sample of 94 Spanish construction companies during the period 2009-2011. This is a period that is characterised by a declining macroeconomic environment in regards to construction.

This research constitutes new empirical evidence in the context of the Spanish construction sector, and contributes to the body of literature on the theory of resources and capabilities, insofar as it shows the need to establish mechanisms that boost competitiveness in companies so as to achieve a balance between growth and profitability. There has been very little research developed in the present decade on the subject of Spanish construction companies. This is in spite of the fact that this activity involves a high risk, is quite demanding [25,26], and has great influence on the Spanish economy in the generation of wealth and employment. The construction sector directly influences other sectors, creating the necessary infrastructure for the development of economic activity and global competitiveness $[8,9,12]$. These considerations make it interesting to empirically identify and analyse the competitive capabilities of these companies, their interrelations, and their ability to explain profitability differentials among companies within the construction sector in Spain.

Interesting conclusions are drawn from the work, both regarding the factors that explain the success and innovative activity in companies, and in the light of new research on this topic. In particular, the results reflect that construction firms can promote higher competitive capabilities for innovation through fostering innovative, financial, and human capabilities within the organisation. Furthermore, they reveal that by fostering those capabilities, construction companies achieve better a performance. Therefore, the results are relevant for the top management of construction companies. They are provided with the key factors that should be especially considered within the strategic orientation of the organisation, in order to gain competitiveness during a recessionary period of the economy. Additionally, the results are relevant for public administrations in order to make them aware of which dimensions should be particularly considered in public policies in order to facilitate sustainable competitive advantages for construction companies in complex economic cycles, such as downturns.

This paper begins with the development of the theoretical framework through the review of previous empirical studies and the presentation of the research hypotheses. Secondly, the methodology is explained, where the sample, the collection of data, and the measurement of the variables used are specified, and the analysis of the results is discussed. Finally, the conclusions, limitations of the study, and possible future investigations are presented. 


\section{Theoretical Background and Hypotheses Development}

The main aim of management activities is to develop processes and capabilities that are able to affect the profitability of firms and foster competitiveness $[27,28]$. The key is to generate a capacity to create a sustainable competitive advantage in relation to competitors $[29,30]$. This creates the difference between successful and unsuccessful firms. Nguyen et al. [31], Norizam et al. [32], and Shahraki et al. [6] pointed out that the key factors to ensure success in construction projects are tools that should be identified and then promoted in order to increase firm efficiency, and, by extension, efficiency in the sector.

The resources-based view analyses the differences in business outcomes, and to what extent a company has the resources and capabilities that can differentiate it from its competitors [33]. In this sense, resource heterogeneity explains the differences in profitability [33,34]. Obtaining a competitive advantage depends on the ability to capture rents in a sustained manner. This ability is a function of how capabilities are used to combine resources [35]. Therefore, the study of resources and capacities is fundamental for the internal analysis and development of competitive strategies. As internal variables are the most important factor when explaining the achievement of competitive advantages [36], the conceptual framework from which this research begins revolves around this theory. Although the environment may affect business activity, the way in which each company approaches its participation in the market defines the way in which it manages its current resources and capabilities [37]. This is the reason apparently identical companies have different degrees of success, as each organisation has unique resources and capabilities that differentiate it from other competitors in its sector [38]. Once these strategic factors have been identified, the company must take appropriate actions to conserve and develop them in a sustained manner over time [29].

Construction has long been criticised for being inefficient and "backward" when compared to some other industries, because of many examples of time overruns, cost overruns, low productivity, and quality problems in construction projects [39]. For these reasons, in recent years, multiple attempts have been made to improve construction success rates [7]. The identification of the factors that are the most strategic for success is crucial in a sector with as much impact as construction has $[3,7]$. The understanding of the relationship between these critical factors will be important for their control, and for making reasonable resource allocations and setting priorities [40]. Although it is not possible to fully ensure success by including these factors, there will always be a greater probability of obtaining it if they exist. Table 1 shows the most recent research papers about this topic in the construction industry. Some studies only relate competitive success to one capacity, but the vast majority reveal the existence of causality, explained by several factors appearing together, albeit with different levels of importance. Another vital element for long-term success and performance in companies in the construction sector is the development of innovative activity [41]. Technology is boosting the implementation of more productive models of management and construction [10]. Innovative companies are more flexible. This is a feature that allows them to better adapt to changes in their environment, and to respond faster and better to the changing needs of society [37].

Table 1. Competitive factors in the construction sector.

\begin{tabular}{|c|c|}
\hline Capabilities & Authors \\
\hline $\begin{array}{l}\text { Innovative } \\
\text { capability }\end{array}$ & $\begin{array}{l}\text { Pellicer, Correa, Yepes, and Alarcón [21]; Seaden et al. [42]; Sexton and Barrett [43]; Barrett } \\
\text { and Sexton [44]; Manleand, Mcfallan, and Kajewski [45]; Lim, Schultmann, and Ofori [46]; } \\
\text { Gambatese and Hallowell [41,47]; Ogunbiyi, Oladapo, and Goulding [48]; Orozco, Serpell, } \\
\text { and Molenaar [49]; Yan and Chew [50]; Horta, Camanho, and Costa [51]; Akhlagh, Moradi, } \\
\text { Mehdizade, and Ahmadi [52]. }\end{array}$ \\
\hline $\begin{array}{l}\text { Marketing } \\
\text { capability }\end{array}$ & $\begin{array}{l}\text { Li et al. [27]; Orozco, Serpell, and Molenaar [49]; Yan and Chew [50]; Takim, Akintoande, } \\
\text { and Kelland [53]; Lu, Shen, and Yam [54]; Butković, Bošković, and Katavić [55]; Fink [56]; } \\
\text { Ling and Hien [57]; Al Badi [58]. }\end{array}$ \\
\hline
\end{tabular}


Table 1. Cont.

\begin{tabular}{|c|c|}
\hline Capabilities & Authors \\
\hline $\begin{array}{l}\text { Financial } \\
\text { capability }\end{array}$ & $\begin{array}{l}\text { Li et al. [27]; Toor and Ogunlana [59]; Tabish and Jha [60]; Chiang, Li, Choi, and Man [61]; } \\
\text { Doloi [62]; Islam and Khadem [63]; Memon, Rahman, Aziz, and Abdullah [64]; Perera, } \\
\text { Rameezdeen, Chileshe, and Hosseini [65]; Shehu, Endut, and Akintoande [66]; Chuan, } \\
\text { Ming, and Lin [67]. }\end{array}$ \\
\hline $\begin{array}{l}\text { Managerial } \\
\text { capability }\end{array}$ & $\begin{array}{l}\text { Li et al. [27]; Takim, Akintoande, and Kelland [53]; Lu, Shen, and Yam [54]; Toor and } \\
\text { Ogunlana [59]; Tabish and Jha [60]; Islam and Khadem [63]; Ng and Tang [68]; Tan and } \\
\text { Ghazali [69]; Doloi, Sawhneand, Iander, and Rentala [70]; Ghoddousi and Hosseini [71]; } \\
\text { Gudiene,, Ramelyte, and Banaitis [72]; Molenaar, Javernick-Will, Bastias, Wardwell, } \\
\text { and Saller [73]; Ribeiro, Paiva, Varajão, and Dominguez [74]; Yong and Mustaffa [75,76]; } \\
\text { Zhang and Fan [77]; Chileshe and Kikwasi [78]; Gudiene, Banaitis, Podvezko, } \\
\text { and Banaitienè [79]; Kiani, Yousefi, Yakhchali, and Mellatdust [80]; Zahedi-Seresht, } \\
\text { Akbarijokar, Khosravi, and Afshari [81]; Heravi, Coffe, and Trigunarsandah [82]. }\end{array}$ \\
\hline $\begin{array}{l}\text { Human } \\
\text { capability }\end{array}$ & $\begin{array}{l}\text { Gudienė, Banaitis, and Banaitienė [26]; Orozco, Serpell, and Molenaar [49]; Takim, } \\
\text { Akintoande, and Kelland [53]; Chan (2009); Toor, and Ogunlana [59]; Chuan, Ming, } \\
\text { and Lin [67]; Ng and Tang [68]; Tan and Ghazali [69]; Doloi, Sawhneand, Iander, } \\
\text { and Rentala [70]; Yong and Mustaffa [76];Chan [83]; Wong, Ng, and Chan [84]; Guerrini, } \\
\text { Martini, and Campedelli [85]; Gudiene, Ramelyte, and Banaitis [72]; Islam and Khadem } \\
\text { (2013); Molenaar et al. [73]; Chileshe and Kikwasi [78]. }\end{array}$ \\
\hline
\end{tabular}

\subsection{The Effects of Innovative Capability on Firm's Innovation and Performance}

Innovative capability is a broad and multidimensional concept that encompasses different aspects of a company, such as planning and management commitment, behaviour and integration, knowledge and skills, information and communication, and external environment [86]. That is, it includes the capacities and abilities that allow the organisation to generate relevant ideas to efficiently elaborate, implement, evaluate, and support innovative strategies. At the same time, they adapt to the external factors of the environment that influence them and the innovative behaviour of the company. Therefore, innovative capabilities reveal whether the company has the essential requirements to perform systematic innovations of products, services, and processes, as well as developing research and development (R\&D). These capabilities determine a company's proximity to the technological frontier, level of scientific and technological information, and the ability to develop and adapt new processes and ways of working.

Technological knowledge and the capability to generate innovations are among the greatest factors of any company, as they make the development of new ideas possible, which are then implemented in the market [42]. The ability to exchange information and intensive knowledge between project and business units, and the codification of the knowledge acquired improves technical competence and supports innovation $[87,88]$. The lack of information becomes an impediment to the development of any creative idea [89]. Companies that have an innovative culture have more capability to try new things and to take risks, so they have a higher degree of innovation [90].

The allocation of resources for research and development activities facilitates innovation [11,47]. R\&D investment continuously improves the technical capabilities of the organisation, and its ability to solve problems. Investment in this area helps to identify and assimilate knowledge, and allows for the generation of innovation [22,91]. Therefore, the potential for construction projects to generate innovations increases when the capacity for innovation grows, especially when a process for innovation management and an innovation incentive scheme are put into place [18]. Considering the previous reasoning, we propose the following hypothesis:

Hypothesis 1 (H1). Innovative capability developed by companies in the Spanish construction sector has a positive influence on their innovation. 
Innovative capabilities appear in the literature as another key factor for success, making the efficient implementation of ideas that increase the competitiveness of the company possible [22]. When the management of the innovation process is standardised to stimulate R\&D and innovation (R\&D\&i) activities in general, as well as to help to achieve the better management of such projects in a structured and systematic way [11], the organisation improves its problem solving, which increases their technical capabilities, knowledge management, business profitability, and client satisfaction [21]. Companies with an innovative capacity have high levels of profitability [51]. The standardisation of R\&D\&i allows for the rapid identification of the activities involved in the creation of new processes, products, and services in the construction company. Therefore, it improves companies' competitiveness in the markets [22,91]. In this sense, the management of the continuous improvement of innovative capability, such as lean construction or construction without losses, increases the productive efficiency of all of the processes, decreasing the costs by reducing waste and making the organisation of the workplace more efficient [48]. Thus, we propose the following hypothesis:

Hypothesis 2 (H2). Innovative capability developed by companies in the Spanish construction sector has a positive influence on their performance.

\subsection{The Effect of Marketing Capability on Innovation and Performance}

Marketing skills allow a company to improve its relationship with its clients and distribution channels [92,93]. The key is to find out the needs, experiences, and motivations of clients, and to determine their attitude toward innovative solutions [94]. The objective is to be able to offer clients the products that most satisfy them [95]. In this sense, the important role of marketing capabilities developed through relationships with clients in innovation promotion in construction is one of the most marked topics in the literature $[87,96,97]$. Innovation can be influenced by the level of sophistication, demand, and competence of the client [98]. The more demanding and experienced the client is [45,98], and the greater technical competence they have, the more they stimulate innovation [88]. They do this by demanding higher standards of work and new specific requirements that must be satisfied for each project. Hence, the relationship with experienced clients provides valuable assets such as reputation and professional contacts. This factor drives the generation of creative ideas and innovative designs that increase the probability of innovative success [99].

Strategies related to relationships and commercialisation are important for small builders when they implement innovations [99]. Thus, cooperation between contractors and clients can act as a catalyst to promote innovative thinking [100]. In fact, companies that manage relationships, such as cooperation or long-term partnerships with clients, are more likely to be innovative [97]. This is so, especially when a framework is established that facilitates collaboration and incorporates a commercial pain/profit model that favours the development of innovations [18]. Thus, they can improve the execution of any type of contract, as these relationships encourage the acceptance of risks when adopting new ideas [89]. This increases the success of innovation through advanced acquisition systems and solid competencies [101].

Attention to users' needs, marketing knowledge, and an in-depth understanding of clients and the market foster success in innovation $[47,95]$. Therefore, marketing capabilities based on access to marketing research, a thorough knowledge of the problem to be solved, and information about the solutions implemented by the competition, lead to finding the uniqueness of a product $[47,97]$. Thus, a positive effect of the marketing capability is expected on a firm's innovation. Following the above reasoning, we propose the following:

Hypothesis 3 (H3). Marketing capability developed by companies in the Spanish construction sector has a positive influence on their innovation. 
Marketing efforts generate synergies that are positively reflected in sales [102]. Client orientation has positive effects on achieving the objectives of projects, as this is a factor that improves the performance of any organisation [56]. Moreover, continuous client support will assist the management team to improve the overall productivity performance [103]. A company has to address the market situation and review its production capacity and strategy in order to satisfy its clients and to remain in the market [11]. Hence, the marketing strategy and the strategic planning and development of the markets are key factors for achieving the greatest profitability [58]. Therefore, marketing strategies and marketing capabilities are important for the sustainability of the construction business [45]. The effective use of marketing capabilities obtains competitive advantages, confirming the importance of marketing differentiation for superior performance [50]. Therefore, a positive effect of marketing capacities on performance is expected.

Hypothesis 4 (H4). Marketing capability developed by companies in the Spanish construction sector has a positive influence on their competitive performance.

\subsection{The Effect of Financial Capability on Innovation and Performance}

Financial capabilities are the set of skills needed to search for and manage sources of financing in a global context, to increase reserves through self-financing and raising capital, to access capital markets, and to obtain external financing at a low average cost [27,49]. The companies that undertake innovative projects must assume high costs in their financing, because of the inherent risk of this type of activity [88].

Companies must allocate adequate resources if they decide to sustain innovation [104]. This implies not only providing a sufficient amount of financial resources [39], but also guaranteeing continued funding $[47,88]$. Therefore, financial considerations play a critical role in the attitude towards innovations based on performance expectations, adopting them only when it is perceived that they are economically favourable [94]. This is particularly important in the case of small-sized construction companies that, because of their limited resources, have less incentive to embark on costly processes such as innovation [11]. Taking into account the contributions indicated above, the fifth hypothesis is the following:

Hypothesis 5 (H5). Financial capability developed by companies in the Spanish construction sector has a positive influence on their innovation.

Several papers show that successful builders are distinguished by their financial capabilities (Table 1). Traditional contracting promotes late payment as well as unrealistic public bidding [76], especially in the case of small contractors in public projects, who tend to delay payments to clients [67]. To improve performance, strategies must be sought that mitigate this opportunistic behaviour, and that improve the relationship among the parties through the development of trust [76]. Loyalty in transactions and financial matters are productive variables [63]. Construction and design processes are prone to important risks such as delays. These delays are caused by contractors and are associated with financial factors such as cash-flow problems. There is a need to overcome this risk in order to carry out successful projects [65].

The lack of financial resources can cause delays or flaws, which negatively affect the company $[66,88]$. In this sense, most of the factors that cause cost overruns are related to financial aspects. Hence, effective financial management can reduce them and improve project success [64]. Construction firms should improve capital use by reducing the size of fixed costs in relation to the variable costs [14]. Planning and control measures are important in the carrying out of the project, as the financial performance of the contractor is linked to the achievement of the cost objectives [103]. Therefore, an experienced contractor and adequate cash-flow during construction improve control and increase the likelihood of obtaining a positive return. On the other hand, a contractor's financial difficulties, and therefore, delays in payments to the subcontractor, affect the overall financial control [62]. Consequently, contractors 
must leverage their experience in accounting and financial management [61]. Consequently, financial capability is a factor of competitiveness [54], contributing to the probability of having sufficient financial resources during the different phases of a project [60]. This is especially true in large-scale projects [59]. Thus, the objective of construction companies from a financial point of view is to have a healthy and stable financial situation [49], because the construction companies that are able to manage their financial resources achieve a higher performance efficiency [7]. Taking into account the contributions indicated, the sixth hypothesis is the following:

Hypothesis 6 (H6). Financial capability developed by companies in the Spanish construction sector has a positive influence on their competitive performance.

\subsection{The Effect of Managerial Capability on Innovation and Performance}

Managerial skills include the ability, talent, knowledge, and willingness of managers to lead the company, managing their operations, making decisions, planning objectives, and selecting and implementing strategies [29]. Managers can increase innovation by changing the organisational structure to encourage the exploration and exploitation of new ideas [41], and promoting an innovative culture within the company $[39,88]$. Innovation and its diffusion depend on the development and maintenance of a climate and culture that encourage, support, evaluate, and reward the generation of new ideas [18,41,88], creative work [105], proactive behaviour, and team spirit [106]. Managers can assure creative problem solving by motivating people and encouraging them to develop new ideas and accept change. Employees can be trained to tolerate risk and share knowledge without fear of losing power, or even their jobs [105]. If managers do not penalise new ways of working when they are not successful, they will promote employees' trust and initiative [88]. In addition, managers have the ability to prevent new ideas from being lost because of daily activity, and to favour an exchange of information and knowledge among project and business units [88].

Innovations arise from improvements in the production, organisation, and management processes [41], and most of all, through the detection of problems [18]. For this reason, managers are increasingly aware of the advantages of planning and controlling innovative activity. Other management processes can adopt a system of standardised innovation to facilitate the incorporation of new ideas and improve the organisation of the company. This, in turn, facilitates the resolution of problems on a regular basis because of increased technical skills and better knowledge management [21,91]. In this sense, Gomez-Conde et al. [107] established that managerial capabilities, along with the use of management accounting tools, boost innovation practices and performance. Therefore, managerial capabilities oriented in this way favour the development of innovations in the company. Taking into account the contributions indicated, the seventh hypothesis is the following:

Hypothesis 7 (H7). Managerial capability in the Spanish construction sector has a positive influence on innovation.

The objective of management is to guarantee a project's success through its synchronisation and control $[40,73,103]$. Therefore, managerial capabilities can lead to success [108], thanks to management support $[7,80,103,109]$, commitment, supervision, and involvement $[6,75]$, as well as monitoring and feedback [60]. Risk identification and management, analysis and goal setting [110], trust and communication, decision-making capability, experience, organisational skills, coordination, competence, and effectiveness for conflict resolution $[4,10,72,79,81]$, are also vital faculties managers must possess. Consequently, we expect a positive effect of this capability on performance, as follows:

Hypothesis 8 (H8). Managerial capability developed by companies in the Spanish construction sector has a positive influence on their performance. 


\subsection{The Effect of Human Resource Capability on Innovation and Performance}

Human capabilities are related to degrees of competence and specialisation, internal communication, motivation, teamwork, and staff turnover [29]. They are the factors that influence productivity performance [103], so they have a vital strategic function, as when implementing any procedure, the intervention of human capital is required [38]. Effective project management starts with the integration of processes and people within a construction project [108]. In this way, the continuous and proactive management of human resources creates a favourable atmosphere for technology and innovation [111]. In small construction companies, the influence of human capabilities is decisive, as the innovation process competes with the day-to-day pressures of the business as a result of the scarcity of resources [11,43]. However, the small scale of their activities provides them with advantages in integrating learning into continuous business processes, and managing internal knowledge flow and employees [99]. The close and long-term relationships between employees and owners create a very motivating business culture, and support creativity and innovation [99]. Thus, innovations are linked to their operational activities [18], which lead them to assimilate technologies implemented through on-the-job learning [44].

Furthermore, there are innovative procedures, such as construction without losses or lean construction, that, with a philosophy of continuous improvement through employee participation and the organisation of the most efficient workplace, involve the worker and generate a sense of belonging. Workers are able to participate in processes by proposing their ideas for improvement [48]. In this sense, staff motivation, satisfaction, attitude, technical competence, and previous experience are important items for innovative success [112]. Furthermore, in order to survive in a highly competitive industry, the development of knowledge is among the most suitable strategies [3]. Chan [83] linked learning and growth, as the development of employees' capabilities leads to greater innovation, improves quality, and increases productivity. Human capital development is an essential step toward the success of the business in the market [113]. Therefore, we propose the following hypotheses:

Hypothesis 9 (H9). Human resource capability developed by companies in the Spanish construction sector has a positive influence on their innovation.

Hypothesis 10 (H10). Human resource capability developed by companies in the Spanish construction sector has a positive influence on their performance.

\subsection{Innovation and Performance}

Previous literature shows evidence of the positive effect of innovation on firm performance [106], reflecting the relevance of the innovation concept in company competitiveness [11]. The construction industry has improved through technology [6]. However, the construction sector is characterised by a low level of innovation $[18,90]$. This is negative for the sector, inasmuch as the lack of innovation affects productivity, quality, and efficiency [24]. Those construction firms that innovate aim their efforts toward taking advantage of changes in the market, carrying out improvements in their systems and processes [96], and introducing new information technologies [42]. As pointed out by Aguilera, González, and Rodríguez [102], firm competitiveness is linked to technology and innovation, because these factors are crucial for survival. Proactive innovation strategies exert a relevant impact on firm performance [52]. Therefore, construction enterprises must reduce costs and improve profit rates by strengthening technological innovations [5]. In this sense, the implementation of processes based on lean construction leads to a decrease in cost, and a more efficient use of resources (effort and time), increasing firm competitiveness [48]. Furthermore, construction firms have to identify innovations that add value for their clients, in order to obtain a sustainable competitive advantage. This advantage can be generated through a reduction in construction costs and time [46]. Process standardisation leads to rapid problem solving, and therefore, to an increase in consumer satisfaction and market competitiveness $[21,91]$. Hence, we propose the following hypothesis: 
Hypothesis 11 (H11). Innovation developed by companies in the Spanish construction sector has a positive influence on their performance.

Figure 1 shows the proposed model, including as control variables size and age of the company.

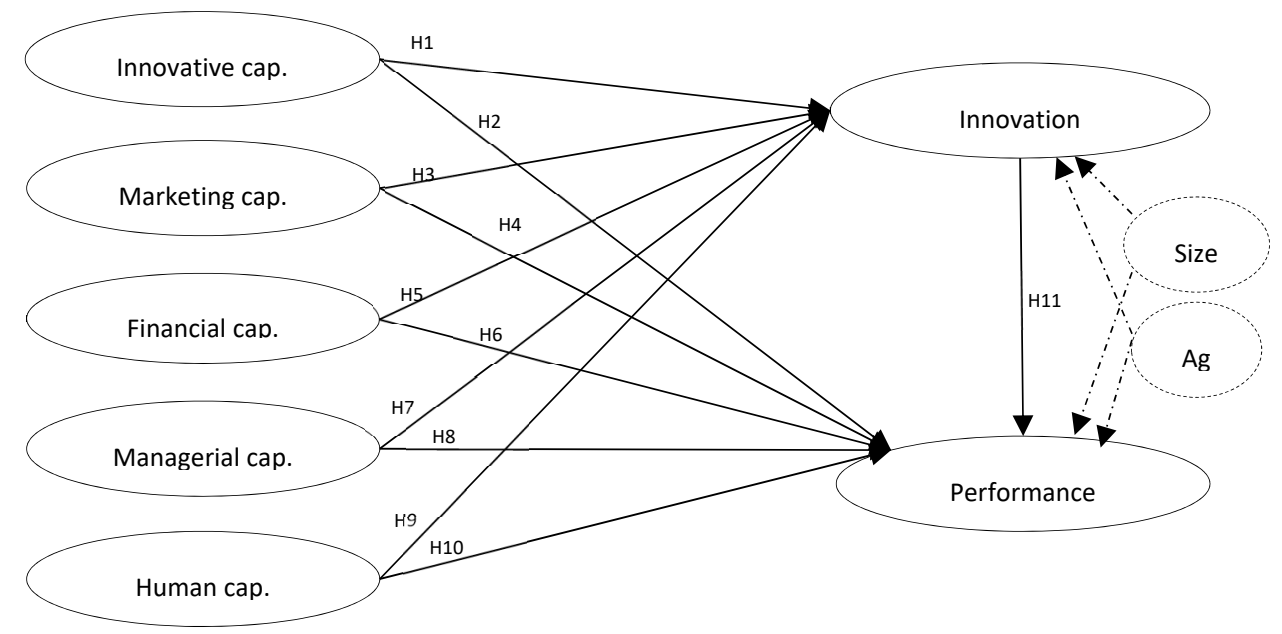

Figure 1. Conceptual model.

\section{Methods}

\subsection{Sample}

The sample size was determined to achieve a maximum error of less than 10 points with $95 \%$ reliability. In order to do this, we considered the information provided by the Company Registration Office, elaborated by the Spanish Statistical Office, to determine the number of firms in each stratum. Data were gathered by means of personal interviews to the managers of the firms. Control tests were carried out when elaborating on the questionnaire used to guide the interviews. Field work took place from April to September 2011, obtaining a final sample composed of 94 firms. Those firms that refused to participate in the study were replaced by similar ones in terms of size and geographic area. Non-response bias was examined considering the method proposed by Nwachukwu et al. [114]. By means of $t$ - and chi-squared tests, we verified that the responses from the first round of interviews (78\%) were similar to those from the last round of interviews (22\%). In order to avoid common variance bias, we ran the Harman test, verifying that this bias is not relevant in this study [115]. The generated principal component analysis output revealed that the first unrotated factor captured only $35 \%$ of the variance in the data. Thus, no single factor emerged, and the first factor did not capture most of the variance. Table 2 reports the sample characteristics. In the sample, $96.8 \%$ of the firms have fewer than 51 employees, $43.6 \%$ are dedicated to general building construction and civil engineering works, $38.3 \%$ are involved in the installations of buildings and works, and $11.7 \%$ to the finishing of buildings and works.

Table 2. Sample.

\begin{tabular}{cccccc}
\hline Activity & $\begin{array}{c}\mathbf{1 - 1 0} \\
\text { Employees }\end{array}$ & $\begin{array}{c}\mathbf{1 1 - 5 0} \\
\text { Employees }\end{array}$ & $\begin{array}{c}\mathbf{5 1 - 2 0 0} \\
\text { Employees }\end{array}$ & Firms & $\%$ \\
\hline Preparation of works & 3 & 3 & 0 & 6 & 6.4 \\
\hline $\begin{array}{c}\text { General construction of buildings and } \\
\text { civil engineering works }\end{array}$ & 17 & 22 & 2 & 41 & 43.6 \\
\hline Installations of buildings and works & 21 & 15 & 0 & 36 & 38.3 \\
\hline Finishing of buildings and works & 7 & 3 & 1 & 11 & 11.7 \\
\hline Total & 48 & 43 & 3 & 94 & 100 \\
\hline
\end{tabular}




\subsection{Measurement Variables}

\subsubsection{Competitive Capabilities}

Recent studies provide different classifications of competitive capabilities, either internationally $[92,93,116]$ in the case of small- and medium-sized enterprises (SMEs) [29,30,38,117,118], or referring to the construction sector $[27,49,63]$. In this research, the most relevant elements of each proposal have been taken into account, to integrate five constructs corresponding to each of the following competitive capacities (Table 3). Innovation capability is that which enables the organisation to make systematic innovations in products, services, and processes; R\&D; and to develop and adapt new processes and ways of working. Marketing capabilities are those that the company has developed for the commercialisation of products or services, as well as the strength of their brands and their positioning. Financial capability is a company's ability to self-finance its operations, and to seek and manage external financing sources in a global context. Managerial capability refers to the ability, talent, preparation, and willingness of managers to efficiently manage the operations of the company. Human capability relates to the set of knowledge and skills of the personnel that make possible the efficient operation of the company, and its survival in the markets in which it intervenes. The questionnaire used to gather the information was elaborated on, considering scales tested in previous literature. To measure each competitive capability, we used a subjective method based on managers' perceptions about their firms' capacity to compete, as this method has been identified as suitable in the case of SMEs [27,49,63,119]. A five-point Likert's scale was used (1: much worse than our competitors; 5 : much better than our competitors). Table 3 shows the items and the previous literature that supports our choice.

Table 3. Competitive capability variables and previous literature.

\begin{tabular}{ll}
\hline \multirow{2}{*}{$\begin{array}{l}\text { Marketing capability } \\
{[27,36,38,93,116,119-121]}\end{array}$} & CC1 Distribution network of our products/services \\
& CC2 Ability to capture and use relevant market information \\
& CC4 Ability to identify potential consumers \\
\hline & FC1 Ability to increase financial reserves through self-financing \\
& FC2 Ability to increase capital through extensions \\
Financial capability & FC3 Ease of access to capital markets \\
{$[27,29,36,49,63,121]$} & FC4 Ability to obtain financing at a low average cost \\
& FC5 Ability to obtain convenient external loans \\
& FC6 Ability to have access to convenient international financing \\
\hline \multirow{2}{*}{ Innovative capability } & IC1 Research and development (R\&D) capability \\
{$[27,36,38,49,116,119-121]$} & IC2 Closeness to the technological frontier of the business \\
\hline Managerial capability & IC3 Level of scientific and technological information \\
\hline $27,36,49,63,117,119,121]$ & MC1 Marketing managerial skills \\
& MC2 Management skills \\
& MC3 Knowledge of global culture \\
\hline \multirow{2}{*}{ Human capability } & HC1 Personnel qualification \\
& HC2 Integration of the personnel in the company \\
& HC3 Staff motivation \\
\hline
\end{tabular}

\subsubsection{Innovation}

Innovation is measured considering both technological and organisational innovations [122]. Technological innovations include product and process innovations, while organisational innovations account for changes in management, marketing, and so on. This classification has previously been used in a relevant number of papers [21,41,42,45,123-126]. Managers were asked to indicate the importance of their product innovation, process innovation, and management and design innovation in comparison with their competitors on a five-point Likert's scale (1: not very important; 5: very important). The items considered have been previously used in the literature $[21,41,42,45,123-126]$. 


\subsubsection{Performance}

Success in construction projects is defined in terms of the extent to which the objectives of the projects have been reached [127]. However, the review of the literature made by Parsanejad, Matsukawa, and Teimoury [128] showed that success in this sector is a complex concept. This complexity is due to the existence of different interest groups and points of view in a project. Each participant in a project will have their own vision $[69,128]$. In general, the most traditional indicators of performance (cost, time, and quality) are considered to be very important when evaluating the competitiveness of any company $[6,7,49,103]$. Nevertheless, there are other indicators, such as client involvement and acceptance $[7,74]$, the satisfaction of the parties, the success of project selection, and its impact on the overall success of the project [128], which have gained importance in recent years. In order to measure the performance of the company, we considered the model proposed by Quinn and Rohrbaugh [129], which is widely used in previous literature [118,130-132]. These authors set a framework distinguishing four models. The model of internal processes is focused on internal control, giving great importance to information communication and considering stability and control as the main goals. The open system model is founded on external flexibility, considering growth, resources, and external support as its main goals. The rational model, which is related to control from an external point of view, focuses on efficiency and productivity criteria. The model of human relations pays attention to flexibility from an internal point of view, to develop the human resources within the firm. To assess these models, 12 items are used (three items per model) with a five-point Likert's scale from one to five (Table 4). As previous literature considers four dimensions in the estimation, we will distinguish among them to build the latent variables of the performance variable.

\subsection{Data Analysis}

The technique used is a structural equation model based on partial least squares variances (SEM-PLS), using the SmartPLS 3.2 software. This estimation method is appropriate, because it has been previously verified that the presence of composite constructs causes identification problems in models of structural equations based on co-variances $[115,133,134]$. SEM-PLS is a method of estimation based on composites, so it does not require strong hypotheses in relation to the distribution of the data, the size of the sample, and the scale of measurement [135].

The objective of this estimation is to optimise the prediction and maximise the explained variance of the endogenous latent variables [135], and as pointed out by Henseler, Hubona, and Ray [136]; SEM PLS is also oriented to the accurate estimation of the parameters. Our model is hierarchical, including a second-order multidimensional construct (performance) in order to take into account the four dimensions identified in the performance variable by previous literature. Thus, our model has been estimated through PLS estimations, using the A mode of estimation in the first step to get the latent variable linked to each dimension of the performance variable, as stated by previous literature, and the B mode of estimation when the second-order multidimensional construct is considered in the structural model.

\subsection{Measurement Model}

\subsubsection{First-Order Composite A Constructs}

To evaluate the reliability and the convergent and discriminant validity of the first-order Composite A constructs, we considered the following indicators (Table 4): composite reliability, factorial loads, average extracted variance (AVE), and the relation between the square root of the AVE of the construct and its correlation with other constructs. In this way, the results show that all of the indicators reach the minimum level required in their factorial loads, being significant in all cases [137]. The reliability was verified through Cronbach's alpha and composite reliability. In this model, the Cronbach's alphas were superior, in all cases, to 0.7 , the minimum recommended. The composite reliability ranged from 0.876 to 0.940 , all exceeding 0.7 , which is the acceptable level suggested by the authors of [138]. Convergent 
validity was verified with the average variance extracted (AVE) for each construct. Thus, this indicator should be above 0.5 [139]. The AVEs of the model were between 0.661 and 0.778 . Table 5 presents the results of the evaluation of reliability analysis and convergent validity.

The discriminant validity of the constructs was analysed considering two criteria [136]. First of all, we verified that the square root of the AVE of the construct is superior to the correlation with other constructs, as recommended in the literature [140] (Table 5). This contrast shows no anomalies, although there were some high correlations (marketing and human capabilities (P1); marketing and management capabilities (P2)). Secondly, the correlations of the Heterotrait-Monotrait ratio (HTMT) of Henseler, Ringle, and Sarstedt [141] were analysed. In this study, the HTMT between each pair of constructs varied from 0.212 to 0.850 , and the bootstrapping analysis shows that the HTMT tests were significantly smaller than 1 , which verifies the discriminant validity of the constructs [136].

Therefore, the first-order Composite A constructs showed good properties in terms of reliability, and convergent and discriminant validity.

Table 4. Measurement model: loadings, construct reliability, and items.

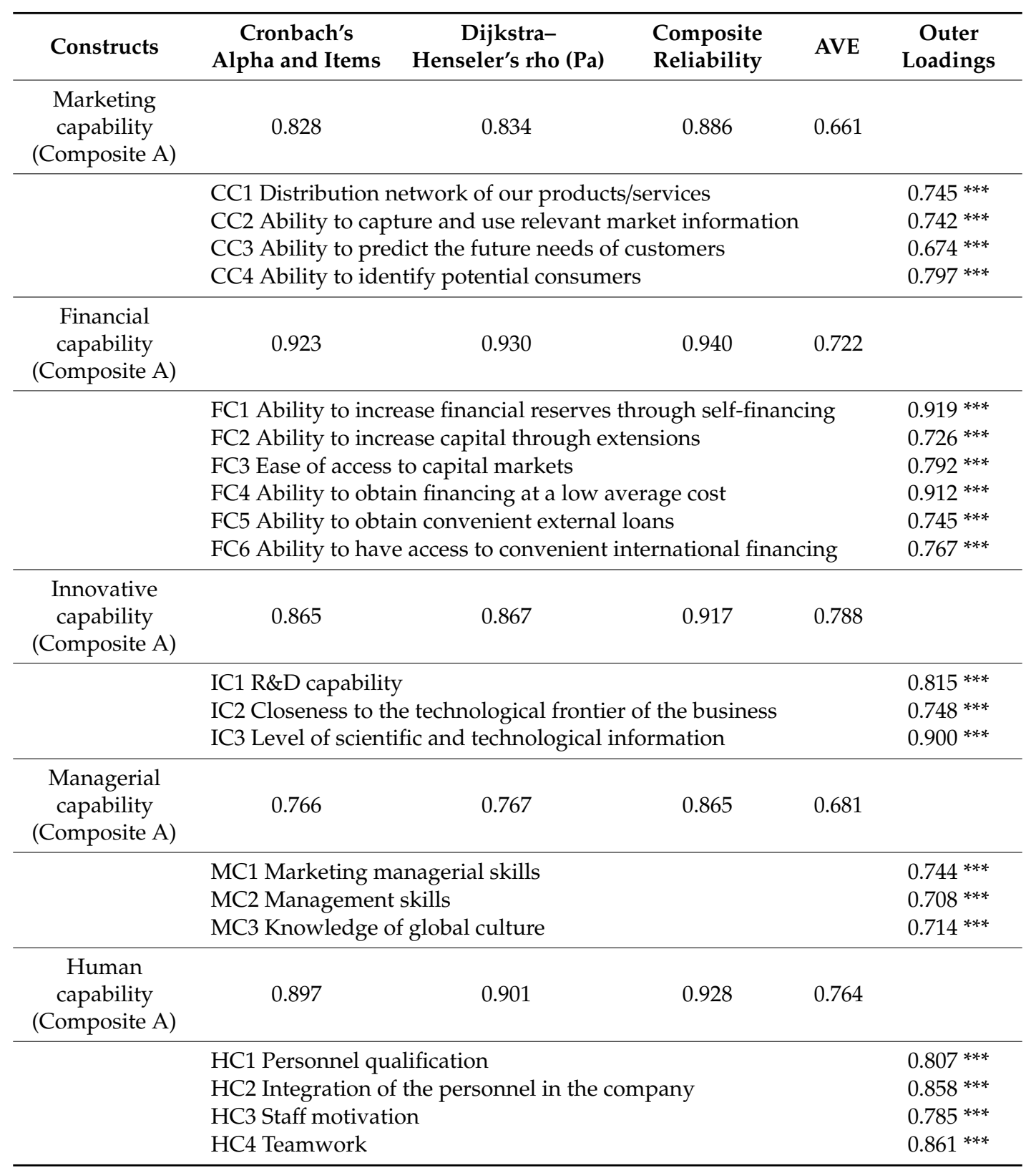


Table 4. Cont.

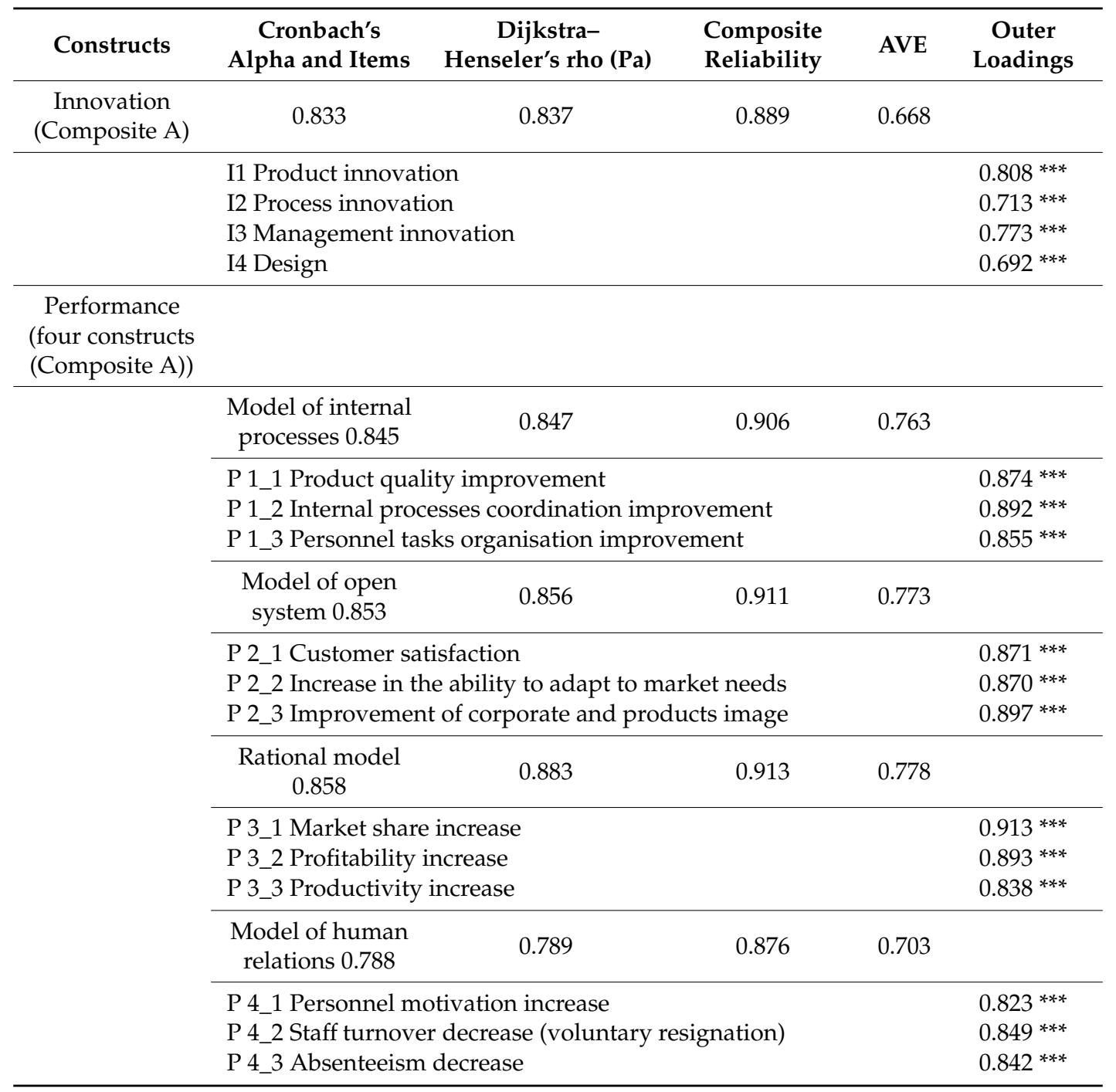

Capability questions: "In comparison with the average position of your competitors, how would you qualify the situation of your company in relation to the following points (1: much worse; 5 : much better)"; Innovation question: "Indicate the importance of the following aspects to your company in the last two years in relation to your competitors' position: (1: not important; 5: very important)"; Performance question: "Indicate the evolution of the following aspects in your company in the last two years in relation to the competitors' position: (1: very unfavourable situation; 5 : very favourable situation)"; AVE—average variance extracted. ${ }^{* * *} p<0.001$; ${ }^{* *} p<0.01$; * $p<0.05$.

Table 5. Measurement model. Discriminant validity evaluation based on the Fornell-Larcker criterion.

\begin{tabular}{|c|c|c|c|c|c|c|c|c|c|c|}
\hline & 1 & 2 & 3 & 4 & 5 & 6 & 7 & 8 & 9 & 10 \\
\hline (1) Marketing capability & 0.813 & & & & & & & & & \\
\hline (2) Financial capability & 0.444 & 0.850 & & & & & & & & \\
\hline (3) Innovative capability & 0.574 & 0.382 & 0.887 & & & & & & & \\
\hline (4) Management capability & 0.619 & 0.469 & 0.563 & 0.825 & & & & & & \\
\hline (5) Human capability & 0.721 & 0.200 & 0.459 & 0.542 & 0.874 & & & & & \\
\hline (6) Innovation & 0.375 & 0.338 & 0.354 & 0.278 & 0.367 & 0.817 & & & & \\
\hline (7) P1 & 0.548 & 0.409 & 0.408 & 0.524 & 0.496 & 0.349 & 0.874 & & & \\
\hline (8) P2 & 0.528 & 0.297 & 0.386 & 0.416 & 0.460 & 0.406 & 0.768 & 0.879 & & \\
\hline (9) P3 & 0.441 & 0.481 & 0.347 & 0.452 & 0.411 & 0.302 & 0.479 & 0.508 & 0.882 & \\
\hline (10) P4 & 0.467 & 0.393 & 0.410 & 0.308 & 0.524 & 0.406 & 0.560 & 0.550 & 0.582 & 0.838 \\
\hline
\end{tabular}

Note: Diagonal row presents the square roof of the AVE. 


\subsubsection{Second-Order Composite B Construct}

The second-order multidimensional construct was approximated by modelling the relationship between the first-order and second-order factors, following the two-step approach proposed by Chin [137]. In the first step, only the dimensions were connected, simulating the proposed model to obtain the scores of the latent variables (latent variable score-LVS). In the second step, the scores of the latent variables were used to measure the multidimensional construct. The Composite B constructs needed to be evaluated differently from the reflective constructs, as traditional validity and reliability analyses (Cronbach's alpha, composite reliability, and extracted mean variance) were not applicable [142].

The quality of the measurement of the second-order construct was evaluated following the indications of Chin [133], and Diamantopoulos and Winklhofer [143]. Thus, we evaluated the correlation between the four first-order constructs. The absolute correlation between them varied from 0.479 to 0.768 . This result suggests that performance should be represented by considering the multidimensional Composite B, rather than the Composite A construct, as a second-order reflective construct would show high correlations between the first order constructs; often above 0.8 [144].

We checked the multicollinearity through the variance inflation factor (VIF) for the four first-order constructs of the multidimensional construct (Table 6). The VIF values were between 1.34 and 2.14. All of VIF values were below 5, so there were no multicollinearity problems [145]. An item in a Composite B dimension must remain in the model when its weight is positive and significant [146]. The weights report on the relative contribution of an indicator to a construct (i.e., the effect of an indicator on the construct once the effect of the other indicators has been controlled) [147]. The loads considered the absolute contribution; that is, the bivariate correlation between the indicator and the construct [148]. The weights of the four dimensions ranged from 0.163 to 0.476 . All of them were significant, except for the one linked to R2 (Table 6). As the loads were significant in all of the cases, we decided to maintain the P2 dimension of the construct [146]. In general, these results showed good measurement properties in the second order construct [137].

Table 6. Second-order construct, measurement model reliability, loadings, VIF, and weights.

\begin{tabular}{cccccc}
\hline First-Order Construct & VIF & Outer Weights & $\boldsymbol{p}$-Value & Outer Loadings & $\boldsymbol{p}$-Value \\
\hline P1 & 2.143 & 0.320 & 0.036 & 0.797 & 0.000 \\
P2 & 2.059 & 0.163 & 0.133 & 0.731 & 0.000 \\
P3 & 1.342 & 0.313 & 0.019 & 0.715 & 0.000 \\
P4 & 1.474 & 0.476 & 0.005 & 0.844 & 0.000 \\
\hline
\end{tabular}

VIF: Variance inflation factor.

\subsection{Structural Model}

The assessment of the global model was carried out considering goodness-of-fit measures. We followed Dijkstra and Henseler [149], taking into account bootstrap-based tests of the model fit over the least squares, and the maximum likelihood and geodesic discrepancy between the empirical and the model-implied correlation matrix (Table 7). The standardized root mean square residual (SRMR) value met the threshold proposed by Hu and Bentler [150]. Table 7 shows that all of the deviations were insignificant, as the $95 \%$ bootstrap quantiles of the value of the three measures were greater than the original values [136].

Table 7. Global model fit.

\begin{tabular}{ccc}
\hline Estimated Model & Original Value & HI95 \\
\hline SRMR & 0.064 & 0.066 \\
Duls & 1.924 & 2.020 \\
Dg & 1.407 & 1.648 \\
\hline
\end{tabular}

Notes: SRMR—standardized root mean squared residual; Duls—unweighted least squares discrepancy; Dggeodesic discrepancy; HI95-bootstrap-based 95\% percentiles. 
To analyse the significance of the relationships raised in each hypothesis, a bootstrapping analysis with 5000 sub-samples was carried out. Most of the coefficients of the model were close to 0.2 , except for those related to hypotheses $2,3,7$, and 8 (Table 8).

The boostrap analysis shows significant Student's $t$-test behaviour in all cases, except for those linked to hypotheses $2,3,7$, and 8 . The values of the $\mathrm{R}^{2}$ varied between 0.189 and 0.450 , rated as good according to Wetzels, Odekerken-Schroder, and Van Oppen [151].

These results show that innovation is affected by innovative capability (0.181), financial capability (0.225), and human capability (0.252). The effects of marketing and managerial capabilities are insignificant. The performance of the company is influenced by its innovation (0.130), and its financial (0.299) and human capabilities (0.324), with the effect of innovative, marketing, and managerial capabilities not being significant.

Table 8. Structural model.

\begin{tabular}{lccccc}
\hline \multicolumn{1}{c}{ Paths } & \multicolumn{3}{c}{ Hypotheses } & \multicolumn{3}{c}{ PLS } \\
\cline { 2 - 6 } & $\mathbf{N}^{\mathbf{0}}$ & Sign & Coefficient & T-Student & Supported \\
\hline Innovative capability $\rightarrow$ Innovation & 1 & + & 0.181 & $1.492^{*}$ & Yes \\
Innovative capability $\rightarrow$ Performance & 2 & + & 0.038 & 0.321 & No \\
Marketing capability $\rightarrow$ Innovation & 3 & + & 0.075 & 0.496 & No \\
Marketing capability $\rightarrow$ Performance & 4 & + & 0.089 & 0.528 & No \\
Financial capability $\rightarrow$ Innovation & 5 & + & 0.225 & $1.745^{* *}$ & Yes \\
Financial capability $\rightarrow$ Performance & 6 & + & 0.299 & $2.316^{* *}$ & Yes \\
Managerial capability $\rightarrow$ Innovation & 7 & + & -0.129 & 0.927 & No \\
Managerial capability $\rightarrow$ Performance & 8 & + & 0.118 & 0.775 & No \\
Human capability $\rightarrow$ Innovation & 9 & + & 0.252 & $1.795^{* *}$ & Yes \\
Human capability $\rightarrow$ Performance & 10 & + & 0.324 & $2.160^{* *}$ & Yes \\
Innovation $\rightarrow$ Performance & 11 & + & 0.130 & $1.346^{*}$ & Yes \\
\hline
\end{tabular}

\begin{tabular}{lc}
\hline Endogenous Variables & Adjusted $\mathbf{R}^{\mathbf{2}}$ \\
\hline Innovation & 0.188 \\
Performance & 0.482 \\
\hline Paths & $\mathbf{f}^{\mathbf{2}}$ \\
\hline Innovative capability $\rightarrow$ Innovation & 0.025 \\
Innovative capability $\rightarrow$ Performance & 0.002 \\
Marketing capability $\rightarrow$ Innovation & 0.002 \\
Marketing capability $\rightarrow$ Performance & 0.005 \\
Financial capability $\rightarrow$ Innovation & 0.044 \\
Financial capability $\rightarrow$ Performance & 0.119 \\
Managerial capability $\rightarrow$ Innovation & 0.010 \\
Managerial capability $\rightarrow$ Performance & 0.013 \\
Human capability $\rightarrow$ Innovation & 0.036 \\
Human capability $\rightarrow$ Performance & 0.090 \\
Innovation $\rightarrow$ Performance & 0.027
\end{tabular}

Notes: Significance of relationships has been estimated using partial least squares (PLS) based on $\mathrm{t}$ (4999); one-tailed $\mathrm{t}$-values; ${ }^{* * *} p<0.001 ;{ }^{* *} p<0.01 ;{ }^{*} p<0.05$. The size (sales) and age of the company have been introduced as the control variables. The coefficients and Students $t$ variables for the relations linked to the control variables are as follows: size $\rightarrow$ innovation: $0.074 ; 0.612$; size $\rightarrow$ performance: -0.085 ; 0.922 ; age $\rightarrow$ innovation: 0.106 ; 1.132 ; age $\rightarrow$ performance: $0.041 ; 0.445$.

\section{Discussion}

The results of this confirmatory model verify $\mathrm{H}_{1}, \mathrm{H}_{5}$, and $\mathrm{H}_{9}$. Therefore, innovative, financial, and human capabilities positively affect innovation in the Spanish construction sector. When construction companies increase their innovative capability during a recessionary period, they achieve more innovation. They work systematically to transform ideas at the project level into knowledge for the whole company [152]. As a result, they improve the capability to exchange information and knowledge between project and 
business units, increasing innovation $[87,88]$. Additionally, financial capability influences firm innovation by facilitating the necessary funds to finance the development of an idea, until it becomes a product or new or improved process in a sufficient and continuous way $[41,47,88]$. Similarly, human capabilities positively affect innovation, as their continuous and proactive management creates an atmosphere favourable to the advancement of technology; this being a fundamental element for the development of innovations. In fact, this capability has the highest coefficient in the model, revealing that it exerts a paramount effect on the innovation of firms. This is important, especially in SMEs [29], where the innovation process competes with the day-to-day pressures of the business because of a lack of resources [43]. In this sense, people are the main source of innovation [21], because of their ability to have creative ideas that involve the resolution of problems [48].

Regarding the effects exerted by marketing and managerial capabilities on firm innovation, the results do not verify the proposed hypotheses. These insignificant coefficients could be due to the effects of the recessionary period. During the crisis, clients tended to award projects based on the lowest costs [46]. In this scenario, regardless of the marketing capability of the construction company, clients' attitudes towards innovative solutions could hinder or even impede innovation [87,94]. Furthermore, an unpredictable demand could hold back investment decisions, as the return of invested capital is not assured [88]. Additionally, the fact that the unique nature of most construction projects limits the degree to which an innovation will be applicable to other situations [87], results in a long period of investment recovery, which is a barrier to the generation of new ideas and their implementation [47]. As a consequence, risk aversion grows and managers prioritise production processes [21], concentrating on satisfying their clients [44] by offering them lower cost products, regardless of the level of managerial capability in the firm. Recently, Matinaro, and Liu [153] have pointed out that the lack of managers' abilities is behind many of the difficulties regarding innovation in construction.

Additionally, performance is influenced by innovation, and marketing, financial, and human capabilities. Consequently, $\mathrm{H}_{6}, \mathrm{H}_{10}$, and $\mathrm{H}_{11}$ are supported. These results are in line with previous research papers. Financial capabilities allow for effective financial management that reduces cost overruns and improves project success [64] by maintaining adequate cash-flow during construction. This increases the probability of achieving a positive performance [62]. The lack of financial resources can cause delays that negatively affect the company [88]. Such delays in delivery may lead to additional costs. All of this can turn what should be a successful project into a failure [66]. Another strategic factor is human capability, as in order to implement any procedure, the intervention of human capital is required [38]. Finally, innovative activity is crucial for the survival and competitiveness of the company, as both are closely linked to the development of technology and innovation [102]. For this reason, many companies acquire different forms of innovation in order to maintain or increase their competitiveness [106], and improve performance [44,51].

The insignificant connections between innovative and management capabilities, and performance may be due to the recession period and the time needed for R\&D investments to become profitable. Companies that improve their innovative capacity do not see increases in profits and returns, until such increases are transformed into a boost in innovation, resulting in new or improved services, products, or processes [88]. Consequently, a rise in innovative capability by itself does not lead to an increase in performance. Furthermore, in times of recession, external constraints cause managers to focus more on ensuring the survival of the company, than on improving its performance. Therefore, fluctuating and unpredictable demand in construction hinders long-term investments, as the invested capital will be returned, depending on the future economic situation, and it becomes complicated to diversify risks and exploit benefits [94].

\section{Conclusions and Implications}

Construction is a highly competitive and high-risk business [25], so companies must take into account the factors that have a direct effect on their success and performance [26]. In addition, the success of companies is also associated with their innovation; that is, the development of new 
products, services, or processes that improve their adaptation to changes and opportunities in the market. Although there are studies that identify competitive factors, the literature for the case of Spanish construction companies is scarce for the period of this decade. The importance of the sector for economic development in Spain $[8,9,12]$ makes it a matter of great interest to identify the competitive capabilities of these companies.

This research analyses, with a sample of 94 Spanish construction companies, the relationship between the capabilities that are deployed by a company to compete in the market, and the success achieved in its innovative activity and performance during a crisis. In this way, the research contributes to increasing the literature on competitive capabilities and innovation, based on the resource-based view, in the context of the Spanish construction sector. The results show that innovative, financial, and human capabilities exert a positive and significant influence on firm innovation. This innovation, as well as the financial and human capabilities, have a positive and significant influence on performance. Therefore, the development of innovations and financial and human capabilities is a strategic decision, with the objective of obtaining a sustainable competitive advantage for construction companies. The conclusions of this research can be useful for entrepreneurs in the sector, as they specify the competitive capabilities that can boost innovative activity and performance, even in a business environment stressed by the economic crisis. Public administrations, in their role as promoters of economic activity, growth, and employment, can use these results to offer new perspectives regarding the importance of their policies in promoting these entrepreneurial skills and innovative activity. The main limitation of this investigation regards the fact that the survey was answered exclusively by the managers of the companies. It would be advisable to restrict the possibilities of biases by taking the perceptions of employees from different hierarchical levels into account [154]. The results shown in this paper cannot be generalised to all the different phases of the economic cycle, as the data was gathered only during the downturn. Future research could be devoted to identifying whether the key capabilities for innovation and performance remain the same during an upward economic period. Longitudinal data should be used in order to test the differences between periods. This research does not consider the patenting activity of the firm to measure innovation [155-157]. Future papers could shed light on how this activity is affecting innovation and performance in the construction sector in Spain, and how SMEs face the knowledge protection/sharing dilemma related to innovation [158].

Author Contributions: Conceptualization, J.G. and A.M.-G.; Data curation, A.D.; Formal analysis, J.G. and A.M.-G.; Investigation, J.G. and A.D.; Methodology, J.G. and A.M.-G.; Resources, A.D.; Software, A.M.-G. and A.D.; Validation, J.G., A.M.-G. and A.D.; Writing-original draft, J.G., A.M.-G. and A.D.; Writing-review \& editing, J.G., A.M.-G. and A.D.

Funding: This research was funded by INSTITUTO DE FOMENTO DE LA REGIÓN DE MURCIA in the framework of the SME Barometer.

Acknowledgments: We thank the anonymous reviewers for their constructive comments.

Conflicts of Interest: The authors declare no conflict of interest.

\section{References}

1. Chang, R.; Zuo, J.; Zhao, Z.; Soebarto, V.; Lu, Y.; Zillante, G.; Gan, X. Sustainability attitude and performance of construction enterprises: A China study. J. Clean. Prod. 2018, 172, 1440-1451. [CrossRef]

2. Ghisellini, P.; Ji, X.; Liu, G.; Ulgiati, S. Evaluating the transition towards cleaner production in the construction and demolition sector of China: A review. J. Clean. Prod. 2018, 195, 418-434. [CrossRef]

3. Yu, D.; Yang, J. Knowledge Management Research in the Construction Industry: A Review. J. Knowl. Econ. 2018, 9, 782-803. [CrossRef]

4. Olanrewaju, A.; Tan, S.Y.; Kwan, L.F. Roles of Communication on Performance of the Construction Sector. Procedia Eng. 2017, 196, 763-770. [CrossRef]

5. Xu, X.; Wang, Y.; Tao, L. Comprehensive evaluation of sustainable development of regional construction industry in China. J. Clean. Prod. 2019, 211, 1078-1087. [CrossRef] 
6. Shahraki, S.; Saghatforoush, E.; Ravasan, A.Z. Identification and Classification of Factors Affecting the Performance of Building Supervisor Engineers for Construction Industry. J. Eng. Proj. Prod. Manag. 2018, 8, 65-74. [CrossRef]

7. Kabirifar, K.; Mojtahedi, M. The impact of Engineering, Procurement and Construction (EPC) Phases on Project Performance: A Case of Large-scale Residential Construction Project. Buildings 2019, 9, 15. [CrossRef]

8. Martín, R.; González, J.; Arguedas, R. Estructura de costes en el sector de la construcción en España. Rev. la Construcción 2012, 11, 17-31. [CrossRef]

9. Martín, R.; González, J. Análisis estratégico de la industria de la construcción en España. Cuad. Gestión 2011, 11, 141-161. [CrossRef]

10. Álvarez, M.Á.; Bucero, A.; Pampliega, C.J. Integrated project delivery, an alternative to the usual form of construction work in Spain = Métodos colaborativos, un cambio para la construcción en España. Build. Manag. 2017, 1, 30-36. [CrossRef]

11. Zubizarreta, M.; Cuadrado, J.; Iradi, J.; García, H.; Orbe, A. Innovation evaluation model for macroconstruction sector companies: A study in Spain. Eval. Program Plann. 2017, 61, 22-37. [CrossRef] [PubMed]

12. Fernández, M.; Fuentes, D. El sector de la construcción en España. Efectos económicos y prospectiva. Boletín Económico ICE 2007, 2928, 49-59.

13. SEOPAN. Informe Económico 2012; SEOPAN: Madrid, Spain, 2013.

14. Kapelko, M.; Horta, I.M.; Camanho, A.S.; Oude Lansink, A. Measurement of input-specific productivity growth with an application to the construction industry in Spain and Portugal. Int. J. Prod. Econ. 2015, 166, 64-71. [CrossRef]

15. Simion-Melinte, C.; Istrate, C. Policy options for the competitiveness of the construction sector in the European Union. In Proceedings of the 8th International Management Conference "Management Challenges for Sustainable Development", Bucharest, Romania, 6-7 November 2014; pp. 370-377.

16. Rubio, A.; Aragón, A. Factores explicativos del éxito competitivo. Un estudio empírico en la pyme. Cuad. Gestión 2002, 2, 49-63.

17. Pellicer, E.; Yepes, V.; Rojas, R.J. Innovation and competitiveness in construction companies. J. Manag. Res. 2010, 10, 103-115.

18. Noktehdan, M.; Shahbazpour, M.; Zare, M.R.; Wilkinson, S. Innovation Management and Construction Phases in Infrastructure Projects. J. Constr. Eng. Manag. 2019, 145, 04018135. [CrossRef]

19. Carbonara, N.; Pellegrino, R. Fostering innovation in public procurement through public private partnerships. J. Public Procure. 2018, 18, 257-280. [CrossRef]

20. Carbonara, N.; Pellegrino, R. The role of public private partnerships in fostering innovation. Constr. Manag. Econ. 2019, 1-17. [CrossRef]

21. Pellicer, E.; Correa, C.L.; Yepes, V.; Alarcón, F. Organizational improvement through standardization of the innovation process in construction firms. Eng. Manag. J. 2012, 24, 40-53. [CrossRef]

22. Correa, C.L.; Yepes, V.; Pellicer, E. Factores determinantes y propuestas para la gestión de la innovación en las empresas constructoras. Rev. Ing. Construcción 2007, 22, 5-14.

23. Guerrero, M.A.; Villacampa, Y.; Montoyo, A. Modeling construction time in Spanish building projects. Int. J. Proj. Manag. 2014, 32, 861-873. [CrossRef]

24. Jensen, C.A. Staged Competition as a Driver of Construction Innovation. Procedia Eng. 2017, 196, $872-879$. [CrossRef]

25. Chan, A.P.C.; Scott, D.; Chan, A.P.L. Factors Affecting the Success of a Construction Project. J. Constr. Eng. Manag. 2004, 130, 153-155. [CrossRef]

26. Gudienè, N.; Banaitis, A.; Banaitienè, N. Evaluation of critical success factors for construction projects-an empirical study in Lithuania. Int. J. Strateg. Prop. Manag. 2013, 17, 21-31. [CrossRef]

27. Li, H.; Li, V.; Skitmore, M.; Wong, J.K.W.; Cheng, E.W.L. Competitiveness factors: A study of the real estate market in China. Constr. Manag. Econ. 2009, 27, 567-579. [CrossRef]

28. Krugman, P. Competitiveness: An International Economics Reader; W. W. Norton \& Co Inc.: New York, NY, USA, 1997.

29. Aragón, A.; Rubio, A. Factores asociados con el éxito competitivo de las pyme industriales en España. Universia Bus. Rev. 2005, 8, 38-51.

30. Rubio, A.; Aragón, A. Recursos críticos y estrategia en la pyme industrial. ICE Trib. Econ. 2009, 846, 193-212.

31. Nguyen, T.A.; Chovichien, V.; Takano, S. Quantitative weighting for evaluation indexes of construction project success by application of structural equation modeling. Int. J. Constr. Eng. Manag. 2013, 2, 70-84. 
32. Norizam, A.; Malek, M.A.; Mohamad, I. Assessment attributes on effective construction management for property developers in Malaysia. J. Sci. Technol. Dev. 2014, 31, 38-48. [CrossRef]

33. Penrose, E.T. The Theory of Growth of the Firm; Basil Backwell: London, UK, 1959.

34. Barney, J. Firm Resources and Sustained Competitive Advantage. J. Manag. 1991, 17, 99-120.

35. Amit, R.; Schoemaker, P.J.H.; Schoemaker, P.J.H. Strategic Assets and Organizational Rent Raphael. Strateg. Manag. J. 2007, 14, 33-46. [CrossRef]

36. Olivares, A.; Coronado, J.A.; Peralta, P.; Guereña, J.M. Factores explicativos de la competitividad para las pymes de manufactura en el Estado de Sonora. Rev. Investig. Académica sin Front. 2014, 7, 1-29.

37. Miles, R.E.; Snow, C.C. Organizational Strategy, Structure and Process; McGraw Hill: New York, NY, USA, 1978.

38. Estrada, R.; García, D.; Sánchez, V.G. Factores determinantes del éxito competitivo en la pyme: Estudio empírico en México. Rev. Venez. Gerenc. 2009, 14, 169-182.

39. Tezel, A.; Koskela, L.; Aziz, Z. Current condition and future directions for lean construction in highways projects: A small and medium-sized enterprises (SMEs) perspective. Int. J. Proj. Manag. 2018, 36, 267-286. [CrossRef]

40. Maya, R.A. Performance Management for Syrian Construction Projects. Int. J. Constr. Eng. Manag. 2016, 5, 65-78.

41. Gambatese, J.A.; Hallowell, M. Enabling and measuring innovation in the construction industry. Constr. Manag. Econ. 2011, 29, 553-567. [CrossRef]

42. Seaden, G.; Guolla, M.; Doutriaux, J.; Nash, J. Strategic decisions and innovation in construction firms. Constr. Manag. Econ. 2003, 21, 603-612. [CrossRef]

43. Sexton, M.; Barrett, P. Appropriate innovation in small construction firms. Constr. Manag. Econ. 2003, 21, 623-633. [CrossRef]

44. Barrett, P.; Sexton, M. Innovation in small, project-based construction firms. Br. J. Manag. 2006, 17, $331-346$. [CrossRef]

45. Manley, K.; Mcfallan, S.; Kajewski, S. The relationship between construction firm strategies and innovation outcomes. J. Constr. Eng. Manag. 2009, 135, 764-771. [CrossRef]

46. Lim, J.N.; Schultmann, F.; Ofori, G. Tailoring competitive advantages derived from innovation to the needs of construction firms. J. Constr. Eng. Manag. 2010, 136, 568-580. [CrossRef]

47. Gambatese, J.A.; Hallowell, M. Factors that influence the development and diffusion of technical innovations in the construction industry. Constr. Manag. Econ. 2011, 29, 507-517. [CrossRef]

48. Ogunbiyi, O.; Oladapo, A.A.; Goulding, J.S. Construction innovation: The implementation of Lean Construction towards sustainable innovation. In Proceedings of the IBEA Conference, Innovation and the Built Environment Academy, London, UK, 7-9 October 2011.

49. Orozco, F.; Serpell, A.; Molenaar, K. Competitiveness factors and indexes for construction companies: Findings of Chile. Rev. la Construcción 2011, 10, 91-107. [CrossRef]

50. Yan, S.; Chew, D.A.S. An investigation of marketing strategy, business environment and performance of construction SMEs in China. Afr. J. Bus. Manag. 2011, 5, 2396-2405.

51. Horta, I.M.; Camanho, A.S.S.; Costa, J.M.; Moreira, J. Performance assessment of construction companies: A study of factors promoting financial soundness and innovation in the industry. Int. J. Prod. Econ. 2012, 137, 84-93. [CrossRef]

52. Akhlagh, E.M.; Moradi, M.; Mehdizade, M.; Ahmadi, N.D. Innovation strategies, performance diversity and development: An empirical analysis in Iran construction and housing industry. Iran. J. Manag. Stud. 2013, 6, 31-60.

53. Takim, R.; Akintoye, A.; Kelly, J. Analysis of measures of construction project success in Malaysia. In Proceedings of the 20th Annual Arcom Conference; Association of Researchers in Construction Management, Heriot Watt University: Edinburgh, UK, 2004.

54. Lu, W.; Shen, L.; Yam, M.C.H. Critical success factors for competitiveness of contractors: A China study. J. Constr. Eng. Manag. 2008, 134, 972-982. [CrossRef]

55. Butković, L.L.; Bošković, D.; Katavić, M. International marketing strategies for Croatian construction companies. Procedia-Social Behav. Sci. 2014, 119, 503-509. [CrossRef]

56. Fink, L. The effect of customer focus competence on construction project performance. Procedia-Social Behav. Sci. 2014, 119, 427-436. [CrossRef] 
57. Ling, F.Y.Y.; Hien, M.B.T. Boosting project outcomes through goal alignment: A case study of Vietnam. Australas. J. Constr. Econ. Build. 2014, 14, 73-86. [CrossRef]

58. Al Badi, K.S. Marketing strategy module. A case study of Oman Cement Company. Int. J. Econ. Commer. Manag. 2015, 3, 1-14.

59. Toor, S.; Ogunlana, S.O. Construction professionals' perception of critical success factors for large-scale construction projects. Constr. Innov. 2009, 9, 149-167. [CrossRef]

60. Tabish, S.Z.S.; Jha, K.N. Important factors for success of public construction projects. In Proceedings of the 2nd International Conference on Construction and Project Management IPEDR; IACSIT Press: Singapore, 2011; Volume 5, pp. 64-68.

61. Chiang, Y.H.; Li, J.; Choi, T.N.Y.; Man, K.F. Comparing China Mainland and China Hong Kong contractors' productive efficiency: A DEA malmquist productivity index approach. J. Facil. Manag. 2012, 10, 179-197. [CrossRef]

62. Doloi, H. Cost overruns and failure in project management: Understanding the roles of key stakeholders in construction projects. J. Constr. Eng. Manag. 2013, 139, 267-279. [CrossRef]

63. Islam, M.A.; Khadem, M.M.R.K. Productivity determinants in Oman construction industry. Int. J. Product. Qual. Manag. 2013, 12, 426-448. [CrossRef]

64. Memon, A.H.; Rahman, I.A.; Aziz, A.A.A.; Abdullah, N.H. Using structural equation modelling to assess effects of construction resource related factors on cost overrun. World Appl. Sci. J. 2013, 21, 6-15.

65. Perera, B.A.K.S.; Rameezdeen, R.; Chileshe, N.; Hosseini, M.R. Enhancing the effectiveness of risk management practices in Sri Lankan road construction projects: A Delphi approach. Int. J. Constr. Manag. 2014, 14, 1-14. [CrossRef]

66. Shehu, Z.; Endut, I.R.; Akintoye, A. Factors contributing to project time and hence cost overrun in the Malaysian construction industry. J. Financ. Manag. Prop. Constr. 2014, 19, 55-75. [CrossRef]

67. Chuan, T.M.; Ming, T.C.; Lin, A.F. Business strategies of small and medium sized contractors in Malaysia. Int. Rev. Basic Appl. Sci. 2014, 2, 131-141.

68. Ng, S.T.; Tang, Z. Labour-intensive construction sub-contractors: Their critical success factors. Int. J. Proj. Manag. 2010, 28, 732-740. [CrossRef]

69. Tan, D.J.; Ghazali, F.E.M. Critical success factors of Malaysian contractors in international construction projects using analytical hierarchy process. In Proceedings of the International Conference on Engineering, Project, and Production Management EPPM, Singapore, 28-30 September 2011; pp. 127-138.

70. Doloi, H.; Sawhney, A.; Iyer, K.C.; Rentala, S. Analysing factors affecting delays in Indian construction projects. Int. J. Proj. Manag. 2012, 30, 479-489. [CrossRef]

71. Ghoddousi, P.; Hosseini, M.R. A survey of the factors affecting the productivity of construction projects in Iran. Technol. Econ. Dev. Econ. 2012, 18, 99-116. [CrossRef]

72. Gudienè, N.; Ramelyte், L.; Banaitis, A. An evaluation of critical success factors for construction projects using expert judgment. In Proceedings of the SCIECONF (Proceedings in Scientific Conference), Virtual Conference, Zilina, Slovania, 10-14 June 2013; pp. 384-389.

73. Molenaar, K.R.; Javernick-Will, A.; Bastias, A.G.; Wardwell, M.A.; Saller, K. Construction project peer reviews as an early indicator of project success. J. Manag. Eng. 2013, 29, 327-333. [CrossRef]

74. Ribeiro, P.; Paiva, A.; Varajão, J.; Dominguez, C. Success evaluation factors in construction project management-some evidence from medium and large Portuguese companies. KSCE J. Civ. Eng. 2013, 17, 603-609. [CrossRef]

75. Yong, Y.C.; Mustaffa, N.E. Critical success factors for Malaysian construction projects: An empirical assessment. Constr. Manag. Econ. 2013, 31, 959-978. [CrossRef]

76. Yong, Y.C.; Mustaffa, N.E. Clients, consultants and contractors' perception of critical success factors for construction projects in Malaysia. In Proceedings of the 27th Annual ARCOM Conference, Bristol, UK, 5-7 September 2011; Egbu, C., Lou, E.C.W., Eds.; Association of Researchers in Construction Management: Bristol, UK, 2011; pp. 735-744.

77. Zhang, L.; Fan, W. Improving performance of construction projects: A project manager's emotional intelligence approach. Eng. Constr. Archit. Manag. 2013, 20, 195-207. [CrossRef]

78. Chileshe, N.; Kikwasi, G.J. Critical success factors for implementation of risk assessment and management practices within the Tanzanian construction industry. Eng. Constr. Archit. Manag. 2014, 21, 291-319. [CrossRef] 
79. Gudienè, N.; Banaitis, A.; Podvezko, V.; Banaitienè, N. Identification and evaluation of the critical success factors for construction projects in Lithuania: AHP approach. J. Civ. Eng. Manag. 2014, 20, 350-359. [CrossRef]

80. Kiani, S.; Yousefi, V.; Yakhchali, S.H.; Mellatdust, A. Identifying program critical success factors in construction industry. Manag. Sci. Lett. 2014, 4, 1325-1334. [CrossRef]

81. Zahedi-Seresht, M.; Akbarijokar, M.; Khosravi, S.; Afshari, H. Construction project success ranking through the data envelopment analysis. J. Data Envel. Anal. Decis. Sci. 2014, 2014, 1-13. [CrossRef]

82. Heravi, A.; Coffey, V.; Trigunarsyah, B. Evaluating the level of stakeholder involvement during the project planning processes of building projects. Int. J. Proj. Manag. 2015, 33, 985-997. [CrossRef]

83. Chan, T.K. Measuring performance of the Malaysian construction industry. Constr. Manag. Econ. 2009, 27, 1231-1244. [CrossRef]

84. Wong, J.M.W.; Ng, S.T.; Chan, A.P.C. Strategic planning for the sustainable development of the construction industry in Hong Kong. Habitat Int. 2010, 34, 256-263. [CrossRef]

85. Guerrini, A.; Martini, M.; Campedelli, B. Measuring the efficiency of the Italian construction industry. Int. J. Bus. Perform. Manag. 2013, 14, 307-325. [CrossRef]

86. Perdomo-Ortiz, J.; González-Benito, J.; Galende, J. Total quality management as a forerunner of business innovation capability. Technovation 2006, 26, 1170-1185. [CrossRef]

87. Blayse, A.M.; Manley, K. Key influences on construction innovation. Constr. Innov. 2004, 4, 143-154. [CrossRef]

88. Hartmann, A. The context of innovation management in construction firms. Constr. Manag. Econ. 2006, 24, 567-578. [CrossRef]

89. Dulaimi, M.F.; Ling, F.Y.Y.; Ofori, G.; De Silva, N. Enhancing integration and innovation in construction. Build. Res. Inf. 2002, 30, 237-247. [CrossRef]

90. Songip, A.R.; Lau, B.H.; Kamaruzaman, J.; Ramli, H.N. A working integrated model for the diffusion of construction innovation. Am. J. Appl. Sci. 2013, 10, 147-158. [CrossRef]

91. Pellicer, E.; Yepes, V.; Correa, C.L.; Alarcón, L.F. The Dilemma of Innovation in the Construction Company: A Decade of Lessons Learned. In Project Management and Engineering Research; Springer: Berlin, Germany, 2017; pp. 21-33.

92. Blesa, A.; Ripollés, M. The influence of marketing capabilities on economic international performance. Int. Mark. Rev. 2008, 25, 651-673. [CrossRef]

93. Ripollés, M.; Blesa, A. International new ventures as "small multinationals": The importance of marketing capabilities. J. World Bus. 2012, 47, 277-287. [CrossRef]

94. Hartmann, A.; Reymen, I.M.M.J.; Van Oosterom, G. Factors constituting the innovation adoption environment of public clients. Build. Res. Inf. 2008, 36, 436-449. [CrossRef]

95. Killip, G.; Owen, A.; Morgan, E.; Topouzi, M. A co-evolutionary approach to understanding construction industry innovation in renovation practices for low-carbon outcomes. Int. J. Entrep. Innov. 2018, 19, 9-20. [CrossRef]

96. Asad, S.; Fuller, P.; Pan, W.; Dainty, A.R.J. Learning to innovate in construction: A case study. In Proceedings of the 21st Annual ARCOM Conference, 7-9 September 2005; Khosrowshahi, F., Ed.; SOAS, University of London, ARCOM: London, UK, 2005; Volume 2, pp. 1215-1224.

97. Akintoye, A.; Goulding, J.S.; Zawdie, G. Construction Innovation and Process Improvement; John Wiley and Sons: London, UK, 2012.

98. Manley, $\mathrm{K}$. The innovation competence of repeat public sector clients in the Australian construction industry. Constr. Manag. Econ. 2006, 24, 1295-1304. [CrossRef]

99. Manley, K. Against the odds: Small firms in Australia successfully introducing new technology on construction projects. Res. Policy 2008, 37, 1751-1764. [CrossRef]

100. Loosemore, M.; Richard, J. Valuing innovation in construction and infrastructure: Getting clients past a lowest price mentality. Eng. Constr. Archit. Manag. 2015, 22, 38-53. [CrossRef]

101. Manley, K. Implementation of innovation by manufacturers subcontracting to construction projects. Eng. Constr. Archit. Manag. 2008, 15, 230-245. [CrossRef]

102. Aguilera, L.; González, M.; Rodríguez, R. Estrategias empresariales para la competitividad y el crecimiento de las pymes. Una evidencia empírica. Investig. Cienc. 2011, 19, 39-48. 
103. Durdyev, S.; Ismail, S.; Kandymov, N. Structural Equation Model of the Factors Affecting Construction Labor Productivity. J. Constr. Eng. Manag. 2018, 144, 04018007. [CrossRef]

104. Dulaimi, M.F.; Nepal, M.P.; Park, M. A hierarchical structural model of assessing innovation and project performance. Constr. Manag. Econ. 2005, 23, 565-577. [CrossRef]

105. Eaton, D.; Akbiyikli, R.; Dickinson, M. An evaluation of the stimulants and impediments to innovation within PFI/PPP projects. Constr. Innov. Inf. Process Manag. 2006, 6, 63-77. [CrossRef]

106. Panuwatwanich, K.; Stewart, R.A.; Mohamed, S. The role of climate for innovation in enhancing business performance: The case of design firms. Eng. Constr. Archit. Manag. 2008, 15, 407-422. [CrossRef]

107. Gomez-Conde, J.; Lunkes, R.J.; Rosa, F.S. Environmental innovation practices and operational performance. The joint effects of management accounting and control systems and environmental training. Account. Audit. Account. J. 2019, 32, 1325-1357. [CrossRef]

108. Demirkesen, S.; Ozorhon, B. Impact of integration management on construction project management performance. Int. J. Proj. Manag. 2017, 35, 1639-1654. [CrossRef]

109. Gunduz, M.; Yahya, A.M.A. Analysis of project success factors in construction industry. Technol. Econ. Dev. Econ. 2015, 24, 67-80. [CrossRef]

110. Zhao, X.; Hwang, B.G.; Low, S.P. Critical success factors for enterprise risk management in Chinese construction companies. Constr. Manag. Econ. 2013, 31, 1199-1214. [CrossRef]

111. Hardie, M.; Newell, G. Factors influencing technical innovation in construction SMEs: An Australian perspective. Eng. Constr. Archit. Manag. 2011, 18, 618-636. [CrossRef]

112. Weng Lou, E.H.; Alshawi, M. Critical success factors for e-tendering Implementation in construction collaborative environments: People and process issues. Electron. J. Inf. Technol. Constr. 2009, 14, 98-109.

113. Lorincová, S.; Hitka, M.; Štarchoň, P.; Stachová, K. Strategic instrument for sustainability of human resource management in small and medium-sized enterprises using management data. Sustainability 2018, 10, 3687. [CrossRef]

114. Nwachukwu, S.L.S.; Vitell, S.J.; Gilbert, F.W.; Barnes, J.H. Ethics and Social Responsibility in Marketing: An Examination of the Ethical Evaluation of Advertising Strategies. J. Bus. Res. 1997, 39, 107-118. [CrossRef]

115. Luo, X.; Li, H.; Zhang, J.; Shim, J.P. Examining multi-dimensional trust and multi-faceted risk in initial acceptance of emerging technologies: An empirical study of mobile banking services. Decis. Support Syst. 2010, 49, 222-234. [CrossRef]

116. Camisón, C.; Villar, A. Effect of SMEs' international experience on foreign intensity and economic performance: The mediating role of internationally exploitable assets and competitive strategy. J. Small Bus. Manag. 2010, 48, 116-151. [CrossRef]

117. Aragón, A.; Rubio, A.; Serna, A.M.; Chablé, J.J. Estrategia y competitividad empresarial: Un estudio en las mipymes de Tabasco. Investig. Cienc. 2010, 18, 4-12.

118. García, D.; Alfaro, E.; Manzaneque, M.; Banegas, R. Strategy, competitive factors and performance in small and medium enterprise (SMEs). Afr. J. Bus. Manag. 2012, 6, 7714-7726.

119. Martínez, R.; Charterina, J.; Araujo, A. Un modelo causal de competitividad empresarial planteado desde la VBR: Capacidades directivas, de innovación, marketing y calidad. Investig. Eur. Dir. y Econ. la Empres. 2010, 16, 165-188. [CrossRef]

120. García, D.; Antón, M.; Bernal, J.J.; Briones, A.J.; Calvo-Flores, A.; Duréndez, A.; Esparza, J.L.; Gálvez, E.J.; González, R.; Madrid, A.; et al. Barómetro Económico de la Pyme 2011; Universidad Politécnica de Cartagena: Cartagena, Colombia, 2011.

121. Aragón, A.; Rubio, A. Factores explicativos del éxito competitivo: El caso de las PyMEs del estado de Veracruz. Contaduría y Adm. 2005, 216, 35-69.

122. AECA. La Innovación en la Empresa: Factor de Supervivencia. Principios de Organización y Sistemas; Asociación Española de de Contabilidad y Admistración de Empresas: Madrid, España, 1995.

123. Giménez, J. Impacto de la innovación sobre el rendimiento de las empresas constructoras: Un estudio empírico en España. FIR-FAEDPYME Int. Rev. 2015, 4, 58-69. [CrossRef]

124. Esmaeili, B.; Hallowell, M.R. Diffusion of safety innovations in the construction industry. J. Constr. Eng. Manag. 2012, 138, 955-963. [CrossRef]

125. Kale, S.; Arditi, D. Innovation diffusion modeling in the construction industry. J. Constr. Eng. Manag. 2010, 136, 329-340. [CrossRef] 
126. Lim, J.N.; Ofori, G.; Park, M. Stimulating construction innovation in Singapore through the national system of innovation. J. Constr. Eng. Manag. 2006, 132, 1069-1082.

127. Takim, R.; Adnan, H. Analysis of effectiveness measures of construction project success in Malaysia. Asian Soc. Sci. 2008, 4, 74-91. [CrossRef]

128. Parsanejad, M.; Matsukawa, H.; Teimoury, E. A comparative framework for measuring project success. Innov. Supply Chain Manag. 2013, 7, 6-18. [CrossRef]

129. Quinn, R.; Rohrbaugh, J. A spatial model of effectiveness criteria: Towards a competing values approach to organizational analysis. Manag. Sci. 1983, 29, 363-377. [CrossRef]

130. Van Auken, H.; Madrid-Guijarro, A.; García-Pérez-de-Lema, D. Innovation and performance in Spanish manufacturing SMEs. Int. J. Entrep. Innov. Manag. 2008, 8, 36-56. [CrossRef]

131. Estrella, E.; Góngora, G.; Martín, M. La innovación en sistemas de control de gestión de las pyme y su relación con el rendimiento. Un estudio empírico. In Proceedings of the XVII Congreso Internacional de Contaduría, Administración e Informática. ANFECA. 3, 4 y 5 de Octubre de 2012; UNAM, Ciudad Universitaria: México, D.F., Mexico, 2012.

132. Hernández, R.; Méndez, S. Exploración factorial del clima y la cultura organizacional en el marco del modelo de los valores en competencia. Rev. PsiqueMag 2012, 1, 1-37.

133. Chin, W.W. Issues and opinion on structural equation modeling. MIS Q. 1998, 22, vii-xvi.

134. Wang, Y.; Chen, Y.; Benitez-Amado, J. How information technology influences environmental performance: Empirical evidence from China. Int. J. Inf. Manag. 2015, 35, 160-170. [CrossRef]

135. Esposito Vinzi, V.E.; Trinchera, L.; Amato, S. PLS Path Modeling: From Foundations to Recent Developments and Open Issues for Model Assessment and Improvement. In Handbook of Partial Least Squares; Springer: Berlin/Heidelberg, Germany, 2010; pp. 47-83.

136. Henseler, J.; Hubona, G.; Ray, P.A. Using PLS Path Modeling in New Technology Research: Updated Guidelines. Ind. Manag. Data Syst. 2016, 116, 2-20. [CrossRef]

137. Chin, W.W. Handbook of Partial Least Squares; Springer: New York, NY, USA, 2010.

138. Bagozzi, R.P.; Yi, Y. On the evaluation of structural equation models. J. Acad. Mark. Sci. 1988, 16, 74-94. [CrossRef]

139. Hair, J.J.F.; Black, W.C.; Babin, B.J.; Anderson, R.E. SEM: An introduction Multivariate Data Analysis: A Global Perspective, 7th ed.; Pearson Prentice Hall: Upper Saddle River, NJ, USA, 2009.

140. Fornell, C.; Larcker, D.F. Evaluating Structural Equation Models with unobservable variables and measurement error. J. Mark. Res. 1981, 18, 39-50. [CrossRef]

141. Henseler, J.; Ringle, C.M.; Sarstedt, M. A new criterion for assessing discriminant validity in variance-based structural equation modeling. J. Acad. Mark. Sci. 2015, 43, 115-135. [CrossRef]

142. Peng, D.X.; Lai, F. Using partial least squares in operations management research: A practical guideline and summary of past research. J. Oper. Manag. 2012, 30,467-480. [CrossRef]

143. Diamantopoulos, A.; Winklhofer, H.M. Index construction with formative indicators: An alternative to scale development. J. Mark. Res. 2001, 38, 269-277. [CrossRef]

144. Pavlou, P.A.; El Sawy, O.A. From IT leveraging competence to competitive advantage in turbulent environments: The case of new product development. Inf. Syst. Res. 2006, 17, 198-227. [CrossRef]

145. Hair, J.F.; Ringle, C.M.; Sarstedt, M. Partial Least Squares Structural Equation Modeling: Rigorous Applications, Better Results and Higher Acceptance. Long Range Plann. 2013, 46, 1-12. [CrossRef]

146. Joseph, F.; Hair, J.; Hult, G.T.M.; Ringle, C.M.; Sarstedt, M. A Primer on Partial Least Squares Structural Equation Modeling. Long Range Plann. 2014, 46, 184-185.

147. Benitez-Amado, J.; Llorens-Montes, F.J.; Fernandez-Perez, V. IT impact on talent management and operational environmental sustainability. Inf. Technol. Manag. 2015, 16, 207-220. [CrossRef]

148. Cenfetelli, R.T.; Basselier, G. Interpretation of formative measurement in information systems research. MIS Q. 2009, 33, 689-707. [CrossRef]

149. Dijkstra, T.K.; Henseler, J. Computational Statistics and Data Analysis Consistent and asymptotically normal PLS estimators for linear structural equations. Comput. Stat. Data Anal. 2015, 81, 10-23. [CrossRef]

150. Hu, L.T.; Bentler, P.M. Cutoff criteria for fit indexes in covariance structure analysis: Conventional criteria versus new alternatives. Struct. Equ. Model. 1999, 6, 1-55. [CrossRef]

151. Wetzels, M.; Odekerken-Schröder, G.; Oppen, C. Van Assessing Using PLS Path Modeling Hierarchical and Empirical Construct Models: Guidelines. MIS Q. 2009, 33, 177-195. [CrossRef] 
152. Bygballe, L.E.; Ingemansson, M. The logic of innovation in construction. Ind. Mark. Manag. 2014, 43, 512-524. [CrossRef]

153. Matinaro, V.; Liu, Y. Towards increased innovativeness and sustainability through organizational culture: A case study of a Finnish construction business. J. Clean. Prod. 2017, 142, 3184-3193. [CrossRef]

154. Cameron, K.S.; Quinn, R.E. Diagnosing and Changing Organizational Culture. Based on the Competing Values Framework; Wiley \& Sons, Inc.: San Francisco, CA, USA, 2006; Volume 16, ISBN 9780787982836.

155. Katila, R. Using patent data to measure innovation performance. Int. J. Bus. Perform. Manag. 2000, 2, 180-193. [CrossRef]

156. Rao, B.C. On the methodology for quantifying innovations. Int. J. Innov. Manag. 2010, 14, 823-839. [CrossRef]

157. Rao, B.C. How to Measure Innovation. Challenge 2010, 53, 109-125. [CrossRef]

158. Olander, H.; Hurmelinna-Laukkanen, P.; Mähönen, J. What's small size got to do with it? Protection of intellectual assets in SMEs. Exploit. Intellect. Prop. to Promot. Innov. Creat. Value 2017, 13, 171-193.

(C) 2019 by the authors. Licensee MDPI, Basel, Switzerland. This article is an open access article distributed under the terms and conditions of the Creative Commons Attribution (CC BY) license (http://creativecommons.org/licenses/by/4.0/). 